(RESEARCH ARTICLE)

\title{
Value of transvaginal ultrasound in preterm delivery
}

Leandro Torriente Vizcaíno 1, *, Martin Cuellar Torriente 2, Danelys Cuellar Herrera 3, Yanet Pérez Rosales 4, Mairim Escalona Gutiérrez ${ }^{5}$

\author{
${ }^{1}$ Obstetrics and Gynecology/Family Medicine. Consultant. Department of Obstetrics and Gynecology and Family \\ Medicine. Julian Grimau Clinic. Havana Medical Sciences University. Cuba. \\ 2 Obstetrics and Gynecology. Professor/Consultant/BscMedSc (Honours). Department of Obstetrics and Gynecology. \\ Manuel Fajardo Clinic. Matanzas Medical Sciences University. Cuba. \\ ${ }_{3}^{3}$ Paediatric. Professor/Consultant. Department of Pediatrics. Juan Manuel Márquez Paediatric Hospital. Havana Medical \\ Sciences University. Cuba. \\ ${ }^{4}$ Family Medicine. Professor/Consultant. Department of Family Medicine. Jimmy Hirzel Clinic. Granma Medical Sciences \\ University. Cuba. \\ ${ }^{5}$ Psychiatric / Family Medicine. Consultant. Department of Psychiatric. Juan Manuel Márquez Paediatric Hospital. \\ Havana Medical Sciences University. Cuba.
}

Publication history: Received on 15 October 2020; revised on 22 October 2020; accepted on 25 October 2020

Article DOI: https://doi.org/10.30574/wjarr.2020.8.1.0393

\begin{abstract}
Prematurity is one of the main causes of neonatal morbidity and mortality and is responsible for a high percentage of infant sequelae, especially in very early gestation ages. Every year an estimated 15 million children are born preterm and this number continues to increase. Approximately 1 million children die each year as a result of the complications of preterm birth. We decide to perform a descriptive and retrospective study of patients admitted to Ángel Arturo Aballí Maternal-Infant Hospital, during the period from July to December 2015.102 patients who were admitted in this center with symptoms of threatened preterm birth, single fetus and intact membranes. The birth and medical records of mothers and newborns were reviewed, as well the statistics department. For the processing and analysis, the SPSS statistical program was used and the results were expressed in numbers and percentages. Results showed that the average age of the mothers was between 20-25 years, the gestational age between 30-34 weeks, the most frequent cervical modification was the shortening of the cervix and most of the patients were managed to reach 37 weeks gestation. It was concluded that transvaginal ultrasound increases the sensitivity and specificity for the diagnosis of preterm delivery and also the shorter of the cervix increase the risk of preterm delivery.
\end{abstract}

Keywords: Cervix; Cervical internal orifice; Premature; Cervical length; Ultrasound

\section{Introduction}

Preterm delivery is a major problem in modern obstetrics in terms of morbidity, mortality and disability for the newborn and cost to society [1].

Preterm delivery is one of the main problems in obstetrics, since it is the cause of 35\% of infant deaths in the first year of life and severe short-term and long-term morbidity in those who survive prematurity. In 2010, Colombia reported $8.8 \%$ of preterm delivery $[2,3]$.

\footnotetext{
${ }^{*}$ Corresponding author: Leandro Torriente Vizcaíno Obstetrics and Gynecology/ Family Medicine. Consultant. Department of Obstetrics and Gynecology and Family Medicine. Julian Grimau Clinic. Havana Medical Sciences University. Cuba. 
Worldwide statistics show strong data, in the United States a prevalence of $11.5 \%$ of preterm births is reported in 2012. While the rate of low birth weight (understood as weight less than 1,500 gr), has been sustained in the course of the years despite the initiatives established. In 2008, a prevalence of $1.46 \%$ and $1.45 \%$ in 2010 . In Spain, according to the Perinatal Medicine Surveys of the Spanish Society of Gynecology and Obstetrics for 2004, the prevalence was $9.1 \%$ and $7,4 \%$ for 2010. On the other hand, Norway reports prevalence according to the World Health Organization (WHO) for 2010 of 6\%, Japan 5.9\%, China 9.1\%, France6.7\%. In Latin America, Mexico is reported with 7.3\%, Brazil 9.2\%, Colombia 8.8\%; while the highest prevalence rates are found in the African continent associated with the difficult access to health services of this population. Reporting Malawi as the country for 2010 with the highest world rate at 18.1\% [1].

In 2005 , preterm births cost at least $\$ 26.2$ million in the United States, $\$ 51,600$ for each child born prematurely, $\$ 6.9$ million (65\%) for health care, \$1.9 million (7\%) for delivery, \$ 611 million (2\%) for early intervention services, $\$ 1.1$ million (4\%) for special education services, \$ 5.7 million (22\%) for loss of homes and labor market productivity [4].

It is suggested that premature birth is not only exposed or prone to suffer from complications inherent to prematurity but also has an impact on school and adult life, thus we have:

\subsection{Neonatal period}

There are a greater number of complications. An increase in the number of cases has been estimated in the last 20 years, which have been depending on Gestational age and fetal weight, which has led to a high consumption of pediatric care.

\subsection{Long-term}

These patients are at greater risk of requiring more hospitalizations for acute processes (pneumonia), and are more likely to present neurological sequelae (Cerebral palsy, eye, hearing and cognitive problems) [5].

\subsection{School life}

There is usually a high rate of school failure, learning problems, repetition of courses or premature cessation of studies. Those under 2500 grams. They are 50\% more likely to need special schools. (The cost of these studies can sometimes exceed those of health) [6].

\subsection{Complication rate of newborns $<1,500 \mathrm{~g}$ at school age}

- $\quad$ No sequelae $64.1 \%$

- $\quad$ Severe sequelae $13.1 \%$

- $\quad$ Mild or moderate sequelae $23.8 \%$

Severe: mental retardation (IQ <50), cerebral palsy with an inability to walk, blindness, deafness. Moderate: mental retardation (IQ: 50-70), hearing loss, cerebral palsy with the ability to walk. Mild: mental retardation (CI: 70-84), impaired coordination, communication, learning or perception [7].

\subsection{Adult life}

In a longitudinal study with 242 survivors born between 1977 and 1979 with GA and average weight of 29.6 weeks and 1179 grams, the secondary graduation rate was significantly lower than the control. The intelligence quotient was lower. The rate of neurosensory problems was 10 times higher (cerebral palsy, hydrocephalus with shunt, blindness, deafness) and the rate of chronic diseases is higher than the control group (Diabetes, asthma, epilepsy, arthritis, etc.) [7].

\subsection{Social}

In the social aspect, they can be presented

- Labour mismatches.

- Loss of working hours.

- Decrease in family income.

- Family breaks (separations and divorces) 
In Cuba, the Obstetrics and Perinatology Standards, updated in 2012, are used as a guiding for all procedures, in which it is detailed as proceed to a patient with symptoms of threatened preterm labour. This may vary depending on the health institution, but it should never be varied or violate what is established here.

Taking this into account, there is room for reflection:

Are all the procedures, techniques, diagnosis and treatment protocols carried out individually for each patient? In order not to treat a single entity but to see the patient as a whole.

\section{Objectives}

To determine the usefulness of transvaginal ultrasound in the diagnosis of preterm delivery.

\section{Theoretical Framework}

\subsection{Definition}

Preterm delivery is defined as that which occurs between 22 and 36.6 weeks of gestation from the date of the last menstruation $[8,9]$.

The Threat of Preterm Labor (TPL) consists of the presence of regular uterine contractions in this same time range, associated with progressive changes of the cervix, such as characteristic dilation and effacement, and is one of the main reasons for a pregnant woman to be admitted before birth $[10,11]$.

\subsection{Risk factors}

They must be identified and intervene in the modifiable ones from the preconception period. The conditions or diseases of the mother or fetus associated with preterm delivery can be summarized as:

Hypertensive disease

Urinary infections.

Premature rupture of ovular membranes.

Twin pregnancy

Bad socioeconomic conditions.

Smoking habit.

Placenta previa

Previous spontaneous preterm births [12,13].

Abruptio placentae.

Anemia.

Polyhydramnios.

Viral and febrile diseases.

Toxoplasmosis.

Cholestasis.

Hepatitis.

Syphilis.

Uterine leiomyoma.

Structural defects of the uterus, congenital or acquired

Cervical incompetence.

Diabetes mellitus.

Nephropathies.

Heart disease.

Thyroid gland disease.

Chorioamnionitis.

Intrauterine devices.

Abdominal surgeries.

In $50 \%$ of preterm births, the cause is unknown. In more than half of these, it is assumed to be due to an infection. Among the most relevant factors are:

Precocious primiparity.

Low stature. 
Previous spontaneous abortions, especially in the second trimester.

Previous induced abortions [11].

\subsection{Early diagnosis of threatened preterm birth}

Presence of frequent, regular and rhythmic uterine contractions (after 22 and before 37 weeks, often between 5 and 8 min or less) or that exceed the contractile pattern.

Cervical modifications described above.

Other warning signs: vaginal leakage, decreased presentation, transvaginal ultrasound results, among others [14].

\subsection{Diagnosis of true preterm labour}

Traditionally, the diagnosis of TPL is based on the presence of uterine contractions and cervical changes. We define uterine contractions as those that are persistent (at least 4 in 20-30 minutes or 8 in an hour) and are considered cervical modifications, the presence of effacement of $\geq 80 \%$ or a cervical dilation of $\geq 2 \mathrm{~cm}$.

The problem with the digital examination to assess cervical changes is that it has great interobserver variability and low predictive power, which leads to an overdiagnosis of TPL and the initiation of treatments in pregnant women who are in fact unlikely to have a preterm delivery. With the consequent risk due to the medication used, due to the increase in unnecessary hospitalizations and even due to the restriction of physical activity that these actions entail.

As a complement to the evaluation of the cervix by vaginal examination and to increase its diagnostic sensitivity, we have markers of preterm delivery such as cervical length measured by transvaginal ultrasound and the fibronectin test (fFN). Although the high negative predictive value of the combination of the negative fFN test and a cervical length $>25$ $\mathrm{mm}$ is known, the cost-effectiveness of using one of the two in combination is currently unclear $[15,16]$.

In pregnant women with TPL, it is recommended to perform a transvaginal measurement of the cervix to determine those that are at high risk of preterm delivery and avoid unnecessary interventions.

To ensure a good predictive value of cervical length, its measurement must be performed appropriately. It is recommended to do it as follows:

- $\quad$ Previous emptying of the urinary bladder.

- Introduce the vaginal probe to the anterior vaginal cul-de-sac, avoiding excessive pressure. The echogenicity of both cervical lips should be similar.

- Obtain a mid-sagittal image of the cervix, identifying the cervical canal and endocervical mucosa, the triangular area of the external cervical os and the V-shaped notch of the internal cervical os.

- $\quad$ Enlarge the image so that the cervix occupies at least $75 \%$ of the image.

- Measure channel distance not including funnel. Fundic pressure may be helpful in revealing the internal cervical os or causing tunnelling.

- $\quad$ Obtain three measurements and record the smallest of them.

Wulff CB [17], stated that in cases of APP with premature rupture of membranes, transvaginal measurement of the neck has also been shown to be useful in predicting the latency time to delivery. For its part, Fuchs I [18] considers that its use is considered safe, although its predictive value in this context is uncertain. (NE: IIb-B) 


\section{Results and discussion}

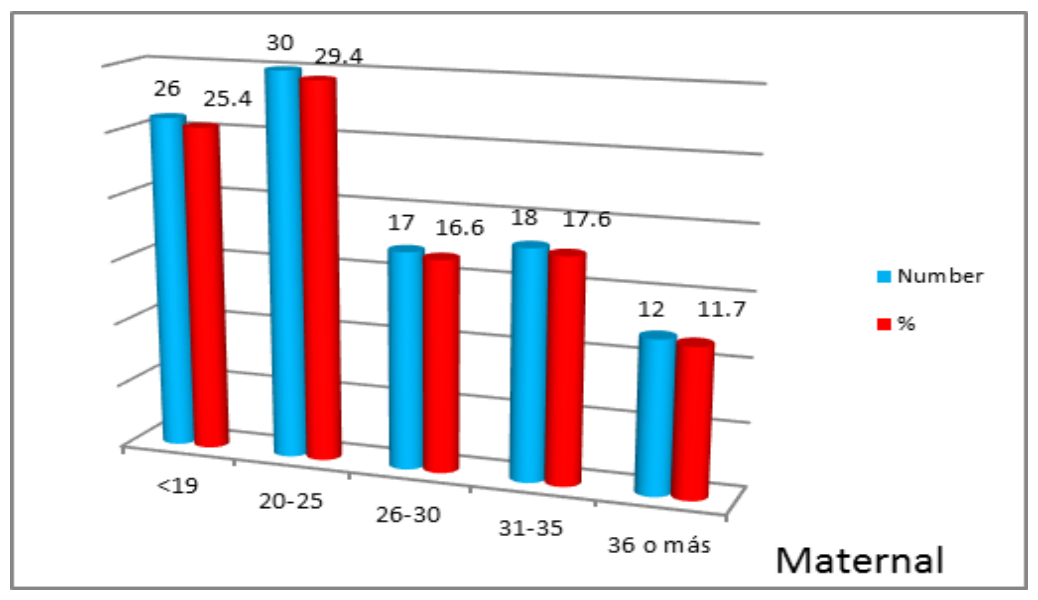

Graph 1 Age distribution of patients with threatened preterm delivery. Hosp A Aballí. July- December 2015 Source HC and Department of Statistics Hosp A A Aballí

This study found that the age in which preterm delivery was most prevalent was between 20 and 25 years, with a total of 30 patients for $29.4 \%$.

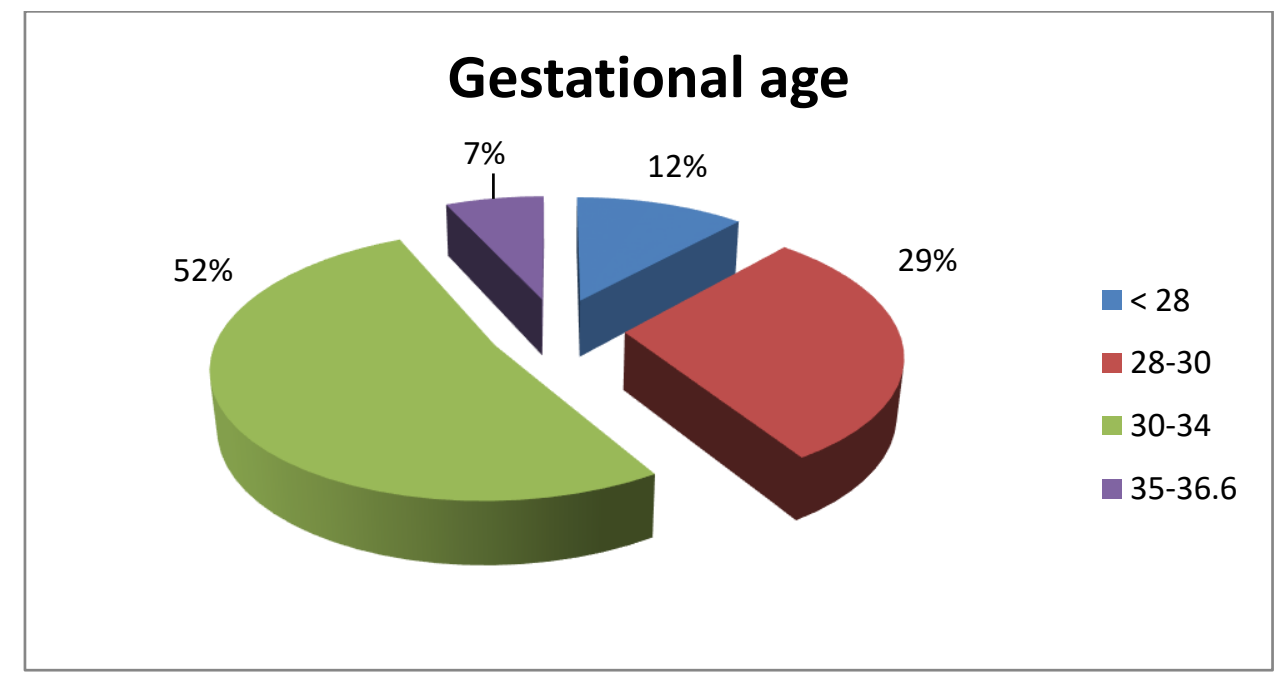

Graph 2 Gestational age of the patients at the time of diagnosis. Hosp A A Aballí. July- December 2015

Source HC and Department of Statistics Hosp A A Aballí

Our study showed that $52 \%$ of the patients, 53 of the 102, were diagnosed between 30 and 34 weeks of gestation. 
World Journal of Advanced Research and Reviews, 2020, 08(01), 188-196

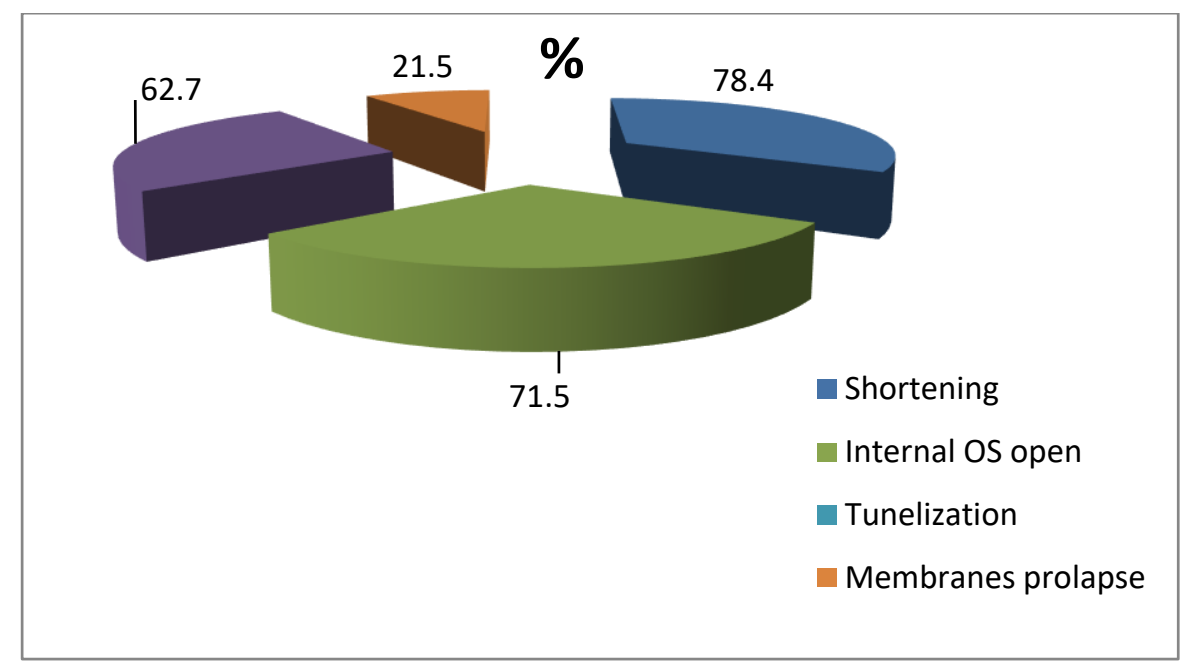

Graph 3 Cervical modifications. Hosp A A Aballí. July- December 2015

Source HC and Department of Statistics Hosp A A Aballí

Shows that performing transvaginal cervicometry could be observed in 80 patients for $78,4 \%$ of the total presented cervical shortening.

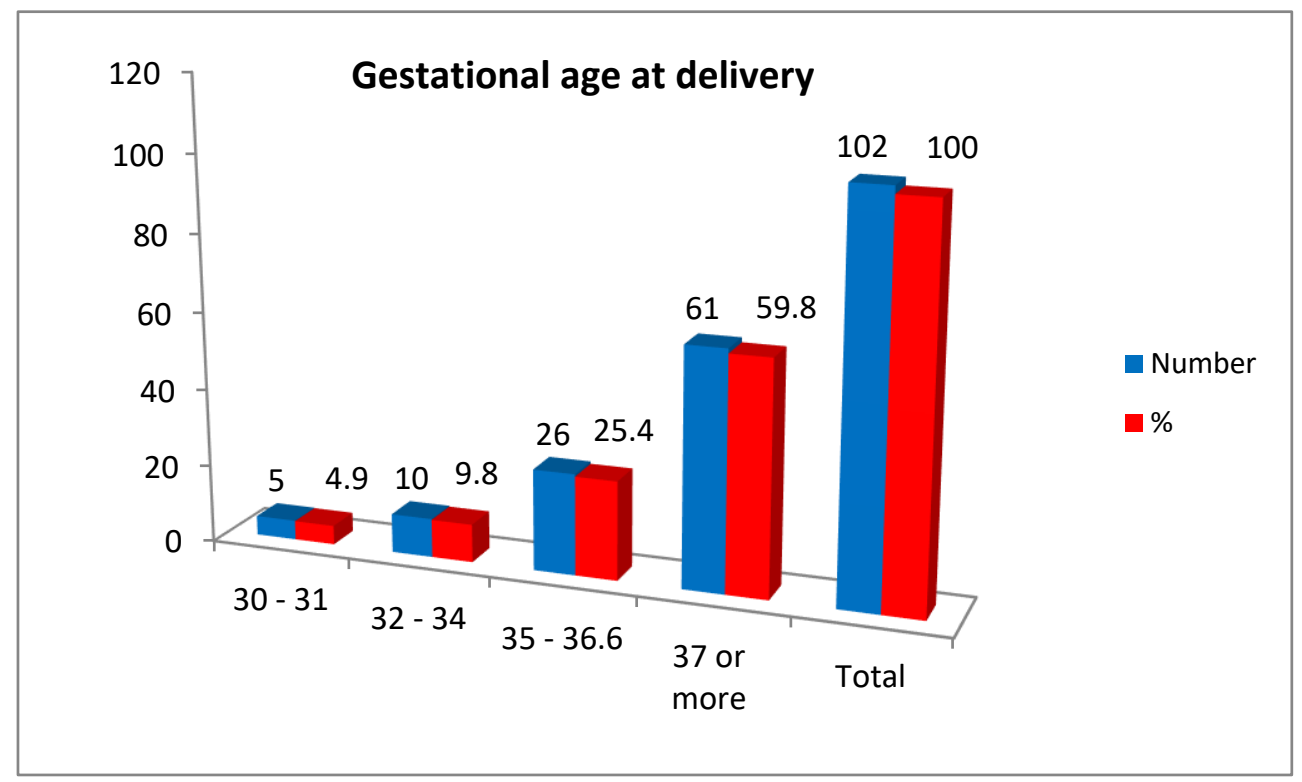

Graph 4 Gestational age at the time of delivery. Hosp A A Aballí. July- December 2015

Source HC and Department of Statistics Hosp A A Aballí

In our series, the patients who reached 37 weeks were 61 for $59.8 \%$.

\section{Discussion}

Rodríguez Blanco CL [19] when relating low birth weight with maternal age, found a coincidence that the largest number of children with this characteristic came from adolescent mothers. For his part, Juan M [20] found maternal age as a risk 
factor, detecting that in the groups under 19 years of age and in those between 20 and 24 years of age, the percentage of preterm births with low weight was higher in the cases.

Even after adjustment for confounders, advanced maternal age (40 years and over) was associated with preterm birth. A maternal age of 30-34 years was associated with the lowest risk of prematurity Fuchs F J [21].

Huai Liu [22] also found that maternal age $\geq 35$ years was associated with elevated risk for preterm delivery before 28 weeks, and maternal age $<25$ years was associated with elevated risk for low birthweight.

Neal S [23] said that the risk of neonatal mortality in all regions was markedly greater for infants with mothers under 16 years old, although there was marked heterogeneity in patterns between regions. Adjusting for socio-economic, demographic and health service

Utilization variables did not markedly change the odds ratios associated with age. The increased risks associated with adolescent motherhood are lowest for first births.

Vera López M [24] found that gestational age at diagnosis is of crucial importance because the unfavourable relationship that exists between lower GA and risk of morbidity and mortality is known. In studies carried out, authors state in their studies that the largest number of patients in their investigations was diagnosed between 33 and 36.6 weeks.

Delivery is preceded by effacement of the neck, the detection of this change during pregnancy, by vaginal ultrasound, can be useful for the prediction of preterm delivery. Vaginal ultrasound is safer and more objective than vaginal examination, as it prevents the carry-over of germs into the neck and measures the portion of the neck above the vaginal fornix [25]. Many authors argue that the transvaginal technique is easier to perform, adequate images can be obtained more frequently with more reproducible results that better correlate with true cervical length compared to transperineal evaluation [26].

Parodi K [27] states that shortening of the cervix before term represents a quantifiable marker of spontaneous preterm delivery. Several causes or pathways of this cervical shortening have been identified, including: congenital, iatrogenic (previous cerclage, conization, or other procedures) and pathological causes, such as premature onset of labor.

In our study, however, it was not possible to demonstrate a statistically significant relationship between cervical length $\leq 25 \mathrm{~mm}$ and a higher risk of presenting preterm delivery and it was not the most affected variable in most cases. The same results were found by Iams JD [28] and Mora Hervása I [29].

Try to delay this type of pregnancy as much as possible is a crucial element and the main objective of every perinatologist. For this purpose all the pertinent measures must be carried out and taken in order to achieve the desired goal. In our series, $59.8 \%$ of the cases reached 37 weeks of gestation. Although, despite these measures, it is up to each patient to respond or not to treatment. Vera et al [24] stated in their series that the average GA at delivery was $33.5+/-$ 2.4 weeks.

\section{Conclusion}

It was concluded that transvaginal ultrasound increases the sensitivity and specificity for the diagnosis of preterm birth and constitutes an indispensable method for making the diagnosis of this common pathology.

\section{Compliance with ethical standards}

\section{Acknowledgments}

The authors were grateful to all people involved in this research.

\section{Disclosure of conflict of interest}

The authors declare that they have no conflict of interest.

\section{Statement of informed consent}

All data published here are under consent for publication. 


\section{References}

[1] José S, Pereira A; Galeas JJ. Longitud del cuello uterino como predictor de parto pretérmino. Articulo original. REVCOG 2017;22:(1):10-13 DOI: http://dx.doi.org/10.37980/im.journal.revcog.2017754

[2] The American College of Obstetrician and Gynecologist. Practice Bulletin. Management of preterm Labor.ObstetGynecol(Internet)2016; 156(1):29-38. doi: 10.1097/AOG.0000000000001265.

[3] Iams J. Identificación de candidatas para Tratamiento con Progesterona ¿por qué, Quien, Cómo, y cuándo? ObstetGynecol. 2014; 123:1317-26. DOI: 10.1097/AOG0276

[4] Mercer BM. Preterm premature rupture of the membranes. Obstet Gynecol 2003;101(1):178-93 DOI: 10.1016/s0029-7844(02)02366-9

[5] Rogowski J. Cost-effectiveness of care for very low birth weight infants. Pediatrics July 1998, 102 (1) 35-43; DOI: https://doi.org/10.1542/peds.102.1.35

[6] Centro de Estudios sobre la Juventud (CEJ); La Habana. $2014 . \quad$ En: https://lib.ohchr.org/HRBodies/UPR/Documents/Session16/CU/CESJ_UPR_CUB_S16_2013_CenroDeEstudiosS obreLaJuventud_S.pdf

[7] Williams Obstetrics, Mc GrawHill 24th Edition 2014, Chapter 42, Pages 829-862. https://www.academia.edu/34505663/Williams_Obstetrics_24th_Ed_PDF_2014_tahir99_VRG

[8] Organización Mundial de la Salud. Partos prematuros. 19 febrero $2018 . \quad$ En: http://www.who.int/es/newsroom/fact-sheets/detail/preterm-birth

[9] Huertas Tacchino Erasmo. Parto pretérmino: causas y medidas de prevención. Rev. peru. ginecol. obstet. [Internet]. 2018 Jul [citado 2020 Jun 02]; 64(3):399-404. Disponible en: http://www.scielo.org.pe/scielo.php?script=sci_arttext\&pid=S2304-

51322018000300013\&lng=es. http://dx.doi.org/https://doi.org/10.31403/rpgo.v64i2104

[10] Hospital Clínico Hospital San Joan de Déu. Protocolo: Amenaza de Parto Pretérmino. Universidad de Barcelona. 2015.En:https://www.academia.edu/28635806/PROTOCOLO_Amenaza_de_Parto_Pret\%C3\%a9rmino_PROTO COLS_DE_MEDICINA_FETAL_I_PERINATAL_HOSPITAL_CL\%C3\%8DNICHOSPITAL_SANT_JOAN_DE_D\%C3\%89U-UNIVERSITAT_DE_BARCELONA

[11] Quirós González G, Alfaro Piedra R, Bolívar Porras M; Solano Tenorio N. Amenaza de Parto Pretérmino. Revista Clínica de la Escuela de Medicina UCR - HSJD Año 2016 Vol 1 No I Rev Cl EMed UCR www. revistaclinicahsjd.ucr.ac.cr. En: https://www.medigraphic.com/pdfs/revcliescmed/ucr-2016/ucr161h.pdf

[12] Escobar-Padilla B, Gordillo-Lara LD, Martínez-Puon H. Factores de riesgo asociados a parto pretérmino en un hospital de segundo nivel de atención Rev Med Inst Mex Seguro Soc 2017; 55 (4): 424-8. In: https://www.medigraphic.com/pdfs/imss/im-2017/im174d.pdf

[13] Ortega Reyes VA, Paredes Paredes JN, Ocampo Moreira PO, Campos Martínez MC; Factores de riesgo y complicaciones de parto pretérmino en adultas en el hospital León Becerra Camacho en el año 2014-2015. Revista Científica Mundo de la Investigación y el Conocimiento. Vol. 3 núm.2, abril, ISSN: 2588-073X, 2019, pp. 449-466 DOI: 10.26820/recimundo/3.(2).abril.2019.449-466

[14] Obstetricia y Perinatología, Diagnóstico y Tratamiento; Parto Pretérmino, Cap 68 Pag. 425-434, Editorial Ciencias Médicas, La Habana 2012.

[15] Sambit Mukhopadhyay, Edward Morris, Sabaratnam Arulkumaran; Algorithms for Obstetrics and Gynaecology, Oxford University Press, Section 2, Page 129 United States, 2014.

[16] RCOG Green-top Guideline No.1b. Tocolysis for women in preterm labour. 2011. In: https://www.guidelinecentral.com/summaries/tocolysis-for-women-in-preterm-labour/\#section-434pdf

[17] Wulff CB, Ekelund CK, Hedegaard M, Tabor A. Can a 15-mm cervical length cutoff discriminate between low and high risk of preterm delivery in women with threatened preterm labor? Fetal Diagn Ther. 2011;29(3):216-23

[18] Fuchs I, Tsoi E, Henrich W, Dudenhausen JW, Nicolaides KH. Sonographic measurement of cervical length in twin pregnancies in threatened preterm labor. Ultrasound Obstet Gynecol. 2004 Jan; 23(1):42-5.

[19] Rodríguez Blanco CL. Algunos factores maternos relacionados con el bajo peso al nacer [Trabajo para optar por el título de especialista de primer grado en Obstetricia y Ginecología]. Hospital "Fe del Valle", Manzanillo 1990. 
[20] Juan M. Vargas Bruqueta Yero; Elvira M. Crespo Bello; Nancy Castillo Lavielle; Factores de riesgo en el parto pretermino. Municipio Bayamo. Año 2010.

[21] Fuchs F, Monet B, Ducruet T, Chaillet N, Audibert F. Effect of maternal age on the risk of preterm birth: A large cohort study. PLoS ONE. 2018;13(1): e0191002. https://doi.org/10.1371/journal.pone.0191002

[22] Huai Liu et al. Preterm birth, low birthweight, and small for gestational age among women with preeclampsia: Does maternal age matter? ELSEVIER. Pregnancy Hypertension. Volume 13, July 2018, Pages 260-266. https://doi.org/10.1016/j.preghy.2018.07.004

[23] Neal S, Channon AA, Chintsanya J. The impact of young maternal age at birth on neonatal mortality: Evidence from 45 low and middle income countries. PLoS ONE. 2018; 13(5): e0195731. https://doi.org/10.1371/journal.pone.0195731

[24] Vera López M and cols; Repercusión del parto pretérmino Hospital Ginecobstétrico Docente Provincial "Ana Betancourt de Mora" Camagüey, Revista "Archivo Médico de Camagüey” 2009; 10(1) ISSN 1025-0255

[25] Manrique $\mathrm{F}$ and cols; Transvaginal ultrasonography as a prognostic factor of preterm delivery, Servicio de Obstetricia y Ginecología. Hospital de León. León. España, 2010 https://doi.org/10.1016/S03045013(04)76011-2

[26] Navarro Briceño $\mathrm{Y}$ and cols; Longitud cervical en el segundo trimestre por ecografía transperineal para la predicción de parto pretérmino. Perinatología y Reproducción Humana. Volume 30, Issue 2, June 2016, Pages 6368. https://doi.org/10.1016/j.rprh.2016.06.003

[27] Parodi K and Jose S; Acortamiento cervical y su relación con parto pretérmino. Rev. fac. cienc. méd. ; 15(1): 2635, 2018. Ilus

[28] Iams JD, Goldenberg RL, Meis PJ, Mercer BM, Moawad A, Das A, et al. The length of the cervix and the risk of spontaneous preterm delivery. N Engl J Med, 334 (1996), pp. 567-72. http://dx.doi.org/10.1056/NEJM199602293340904

[29] Mora Hervása I et al. Valor de la medición ecográfica de longitud cervical en gestantes con amenaza de parto prematuro para predecir un parto pretérmino. Progresos de Obstetricia y Ginecología. ELSEVIER. 2006.Vol. 49. Núm. 1. Páginas 5-11 DOI: 10.1016/S0304-5013(06)72556-0 